\title{
Comparative Evaluation of Population Effect and Economic Potential of Biological Suppression Tactics Versus Chemical Control for Squash Bug (Heteroptera: Coreidae) Management on Pumpkins
}

\author{
D. L. OLSON, ${ }^{1}$ J. R. NECHOLS, ${ }^{2}$ AND B. W. SCHURLE ${ }^{3}$
}

\begin{abstract}
J. Econ. Entomol. 89(3): 631-639 (1996)
ABSTRACT Field releases of the indigenous egg parasitoid Gryon pennsylvanicum (Ashmead) resulted in a 4-fold reduction in squash bug, Anasa tristis (De Geer), densities on 'JackO-Lantem' pumpkins in 1991. However, pest populations subjected to parasitoids were consistently higher, and fruit yields and quality lower, than on plants that were treated with the insecticide, esfenvalerate. When the squash bug-resistant 'Green-Striped Cushaw' was used, the difference in pest densities on parasitoid-released and insecticide-treated plants was only half of that observed on the susceptible cultivar. In 1992, under abnormally wet, cool conditions, squash bug densities were higher on insecticide-treated plants and lower on plants where parasitoids were released than in 1991. Fruit quality for both cultivars was substantially reduced in all treatments in 1992. The wet, cool conditions apparently had less of an effect on pest densities and fruit yields on resistant pumpkins than on susceptible pumpkins. The expected net income for insecticide-treated pumpkins was substantially lower in 1992 than in 1991. Where biological control and host plant resistance were combined, loss in expected net income in 1992 was considerably less than in 1991. Although costs associated with biological control were very high relative to the revenues, integrating biological control with host plant resistance may have some potential as an alternative management strategy.
\end{abstract}

KEY WORDS Gryon pennsylvanicum, biological control, economic analysis

The SQUaSH BUC, Anasa tristis (De Geer), is a serious insect pest of squash and pumpkins throughout the United States (Nechols 1985, 1987; Fargo et al. 1988, Bonjour and Fargo 1989, Paige et al. 1989). Control of squash bugs with insecticides is difficult to achieve because eggs are deposited continuously during the growing season (Fielding 1987, Nechols 1987). Squash bugs also tend to occupy locations on or near host plants that protect them from sprays (Nechols 1985, Palumbo et al. 1990). Finally, adults and late instar nymphs are controlled poorly by most registered insecticides (Zavala 1991). These factors, coupled with rising insecticide costs and increased concerns for environmental protection and human safety, indicate the need to develop and implement alternative management tactics for squash bugs.

Previous research has shown that alternative tactics are available, including cultural control (Palumbo et al. 1991) and host plant resistance (Novero et al. 1962, Paige et al. 1989). With regard to

\footnotetext{
'Department of Entomology, The University of Georgia, Griffin (.A 30223

Department of Entomology, Kansas State University, Manhat$\tan \mathrm{KS} 66506$.

${ }^{3}$ Department of Agricultural Economics, Kansas State University, Mamhattan KS 66506.
}

biological control, a naturally occurring tachinid fly, Trichopoda pennipes F., parasitizes last instar nymph and adult squash bugs (Worthley 1924, Dietrick and van den Bosch 1957). A number of hymenopteran egg parasitoids also are known to attack the squash bug (Schell 1943, Nechols et al. 1989). Comparative studies have shown that one naturally occurring scelionid wasp, Gryon pennsylvanicum (Ashmead), may be useful as a biological control agent (Nechols et al. 1989). However, because $G$. pennsylvanicum occurs late in the growing season and is found at low densities under natural field conditions, an augmentative approach appears necessary.

Although a number of studies have been made, of the biology of the squash bug (Beard 1940, Fielding 1987, 1988; Nechols 1987, 1988; Fielding and Ruesink 1988) and management (Fargo et al. 1988), the impact of biological control agents has never been assessed. Furthermore, economic data are unavailable for any squash bug pest management tactic. In fact, the economic feasibility of biological control has been assessed for only a few horticultural pests, including spider mites on almonds (Headley and Hoy 1987) and cassava (Norgaard 1988). Also, no previous study has investi- 
gated the integration of alternative management tactics for the squash bug. Therefore, our objectives were to evaluate experimentally the suppressive ability and economic potential of an augmentatively released natural enemy, G. pennsylvanicum, of the squash bug on pumpkins; compare the impact and economic feasibility of biological control versus conventional chemical control; and determine whether the integration of augmented parasitoids and resistant pumpkin cultivars might result in greater pest suppression and increased economic feasibility for commercial growers.

\section{Materials and Methods}

Field Experiments. During 1991 and 1992, experiments were conducted on a sandy-loam soil along the Kansas River $(19.3 \mathrm{~km}$ south of Manhattan, KS). Two pumpkin cultivars were used: 'Jack-O-Lantern' (Cucurbita pepo L. variety pepo), a susceptible pumpkin cultivar and 'Green-Striped Cushaw' Cucurbita mixita, Pang. (Duchesne), a resistant green pumpkin cultivar. All plants were grown from seed in a greenhouse for 1 mo (about the 4-leaf stage) and then transplanted to the field on 9 July 1991 and 1 July 1992. The herbicide Amiben (Rhone-Poulenc, Research Triangle Park, $\mathrm{NC}$ ) was soil-incorporated $3 \mathrm{~d}$ before planting at a rate of $16 \mathrm{~kg}(\mathrm{AI}) / \mathrm{ha}$. Also at this time, granularformulated fertilizer (N:P:K $68 \mathrm{~kg}, 111 \mathrm{~kg}$, and 111 $\mathrm{kg} / \mathrm{ha}$, respectively) was applied directly over marked rows using a hand spreader. Plots were watered to a depth of $2.5-4.5 \mathrm{~cm}$ at planting and every $7 \mathrm{~d}$ as needed. Because natural infestations of squash bugs cannot be predicted, and to increase uniformity of infestation, 50 field-collected adult, female squash bugs were mated and released into each plot $1 \mathrm{wk}$ after transplanting.

Each experiment consisted of 3 main treatments: biological control (releases of G. pennsylvanicum adults); chemical control (tank-spray of Asana XI. [esfenvalerate 0.66 emulsifiable concentrate (EC), Dupont, Wilmington DE]); and untreated plots that served as a control. Host plant resistance served as a subcomponent of each treatment. Each treatment, including the control, was replicated 4 times. Experimental plots consisted of 4 rows (2 each of the susceptible and resistant cultivar) with 5 plants per row. Plants were spaced equally within cultivars $(1.83 \mathrm{~m})$ and between cultivars $(3.66 \mathrm{~m})$. To reduce insecticidal drift or parasitoid dispersal among treatments, all plots were separated by a $61 \mathrm{~m}$ fallow area. Preliminary research showed that a sorghum border around the plots did not reduce dispersal of parasitoids compared to an open field plot, so experiments were conducted in field plots without borders.

Natural Enemy Releases. When surveys showed that plots had an average of 1 squash bug egg mass per plant, total eggs per plot were estimated by multiplying the number of egg masses by a factor of 15 , which represents the average number of eggs in a squash bug egg mass. One-day-old, mated, female parasitoids from a laboratory colony were released by placing 2-dram vials under the plant canopy, evenly among host eggs. A release ratio of 1 parasitoid for every 17 squash bug eggs was used, based on the reproductive schedule of $G$. pennsylvanicum reported by Nechols et al. (1989). The 1st releases were made on 24 and 15 July in 1991 and 1992, respectively; weekly releases were maintained for 5 consecutive weeks. During 1992, in addition to the weekly releases, biweekly releases were made at $1 / 2$ the computed rate of the previous release. Estimates of squash bug eggs were made weekly to determine numbers of female parasitoids to release. Because parasitoids were released before plant flowering, a supplemental source of nutrition (honey-water solution) was provided throughout the release period.

Pesticide Application. When squash bug nymphs were first observed $(\approx 7 \mathrm{~d}$ after the 1 st eggs were found), esfenvalerate was applied at a rate of $424 \mathrm{ml}(\mathrm{AI}) / 935$ liters $\mathrm{H}_{2} \mathrm{O} / \mathrm{ha}$, with a backpack hand sprayer. A constant pressure of $60 \mathrm{psi}$ was maintained, and the spray was directed to all plant surfaces.

Sprays were made during the early morning or evening hours every $12 \mathrm{~d}$ until $3 \mathrm{~d}$ before harvest. With the exception of a fungicide (see below), no pesticide treatment was applied to plants in the control or biological control plots.

Powdery mildew, Erysiphe cichoracearum DC, is a fungal pathogen that may cause considerable damage to pumpkins from late August to early September. Therefore, Bayleton 50 wettable powder (WP) (triadimeton, Miles, Kansas City, MO) was applied at a rate of $59 \mathrm{ml}(\mathrm{AI}) / 37 \quad 1 \quad \mathrm{H}_{2} \mathrm{O} / \mathrm{ha}$ when initial symptoms appeared. Subsequent applications were made at about 14-d intervals. Fungicide was applied only to infested leaves.

Sampling Procedures. A $10-\mathrm{m}^{2}$ area (the area covered by 3 plants) was selected randomly from each plot weekly until fruits were harvested. On the soil surface and on all plant foliage within this area, squash bugs were counted and classified as adults; nymphs (combined as either 1st, 2nd and $3 \mathrm{rd}$, or 4th and 5th instars); and eggs (number of egg masses and number of eggs per mass). All counts were divided by three and recorded as per plant counts. Egg masses were examined with a $10 \times$ hand lens to determine hatched, parasitoidemerged, or intact (no eclosion hole) eggs. To distinguish the sample dates, different colors of nail polish were dotted onto the leaf tissue beside unmarked egg masses. Thus, egg masses examined previously could be reexamined on successive sample dates for additional hatched or parasitoidemerged eggs. Because older leaves senesce, resulting in loss of egg masses, eggs that did not hatch or produce parasitoids within 2 wh of the initial examination were put into mesh bags to prevent moisture accumulation and allow parasitoid emergence. Bags were labeled and tied to a plant 
Table 1. Mean \pm SE densities of squash bug nymphs and adults on a resistant and a susceptible cucurbit cultivar with and without biological or chemical control in 1991 and 1992

\begin{tabular}{lrrrrr}
\hline \multirow{2}{*}{ Treattment } & \multicolumn{3}{c}{ Squash bugs/plant } \\
\cline { 2 - 5 } & \multicolumn{3}{c}{1991} & & \multicolumn{1}{c}{1992} \\
\cline { 2 - 5 } & JOL \pm SEM & GSC \pm SEM & & JOL \pm SEM & GSC \pm SEM \\
\hline Biological control & $18.6 \pm 5.9 \mathrm{Aa}$ & $7.1 \pm 2.8 \mathrm{Ab}$ & & $7.1 \pm 5.1 \mathrm{Aa}$ & $2.5 \pm 1.5 \mathrm{Ab}$ \\
Chemical control & $1.1 \pm 1.4 \mathrm{Ba}$ & $0.5 \pm 0.4 \mathrm{Ba}$ & & $2.5 \pm 1.0 \mathrm{Aa}$ & $1.2 \pm 0.8 \mathrm{Aa}$ \\
No treatment & $73.2 \pm 30.7 \mathrm{Ca}$ & $35.4 \pm 13.3 \mathrm{Cb}$ & & $16.4 \pm 9.0 \mathrm{Ba}$ & $16.8 \pm 8.5 \mathrm{Ba}$ \\
\hline
\end{tabular}

JOL, Jack-O-Lantern (susceptible); GSC, Green-Striped Cushaw (resistant). Means followed by the same letter are not significantly different (GL,M, LSD, P $\leq 0.05$ ). Uppercase letters are within cultivar; lowercase letters are between cultivars. LSIDs were computed using square-root transformed data.

vine in the lower canopy that was nearest the place of oviposition. Egg predation by ants and other natural enemies is possible, but this was not determined.

Density estimates of adult spotted cucumber beetles, Diabrotica undecimpunctata howardi Barber, and striped cucumber beetles, Acalymma vittatum $\mathrm{F}$., were made on a weekly basis from time of initial infestation. If a plant collapsed suddenly with no apparent foliar damage, the roots were examined for cucumber beetle larval feeding or the stems were examined to determine whether squash vine borer, Melittia cucurbitae (Harris), was present.

Within a week of the lst hard frost, pumpkins were harvested, counted, and weighed to determine yield for each plot. To assess qualitative damage, pumpkins were graded according to the following U.S. grades. No. 1: uniform, well matured, and free from any form of damage; No. 2: uniform, fairly well matured, and free from any form of serious damage; or unacceptable-tender outer shell, broken, cracked, split open, or damage scars covering $>10 \%$ of the surface (USDA 1983).

Dita were analyzed using a general linear model (PROC GLM). Square-root transformations were used to compute the least significant difference (ISD) of means at the $P \leq 0.05$ level (SAS Institute 1990). Voucher specimens of the squash bug and $G$. pennsylvanicum have been deposited under lot number 056 in the Entomology Research Collection at Kansas State University (Manhattan, KS).

Economic Analysis. For each treatment (biological control, chemical control or untreated) on each cultivar (resistant or susceptible), cost-benefit ratios were computed and compared. Data were obtained only for those costs and revenues (benefits) that were unique for each treatment.

Potential revenues for each treatment were calculated by multiplying the total weight per hectare for each grade of fruit by the current retail prices. The current retail prices were $\$ 0.33 / \mathrm{kg}$ and $\$ 0.26 /$ $\mathrm{kg}$ for U.S. No. 1 and No. 2 grades, respectively. Unacceptable pumpkins were culled at harvest, and counts were recorded to assess loss in revenue for each management tactic. For each cultivar and experimental treatment, the numbers of culls were multiplied by the combined average weight for U.S. No. 1 and No. 2 grades. Total weight per hectare for culls was then multiplied by the combined average price $(\$ 0.30 / \mathrm{kg})$ for U.S. No. 1 and No. 2 grades to determine loss in revenue.

Biological control costs included costs of obtaining $G$. pennsylvanicum. The costs of rearing this parasitoid in a greenhouse were estimated, and the estimated cost of purchasing G. pennsylvanicum was obtained from commercial insectaries or suppliers. Because G. pennsylvanicum is not reared commercially, a telephone survey was conducted of commercial insectaries and suppliers of beneficial species that use a production system similar to what would be required to mass-rear $G$. pennsylvanicum. Overhead and labor costs per $0.09 \mathrm{~m}^{2}$ for greenhouse production in Kansas (A. B. Stevens, Department of Horticulture, Forestery \& Recreation Resources, Kansas State University, personal communication) were used to project the cost of rearing G. pennsylvanicum in the greenhouse. The difference in price of seed for the susceptible JackO-Lantern and the resistant Green-Striped Ci1shaw was used to estimate the cost of host plant resistance. The current price of insecticide for squash bugs was used to estimate the cost of chemical control for repeated applications.

Partial budget analysis (Boehlje and Eidman 1984) was used to determine the economic potential of using biological suppression tactics compared to chemical control for the squash bug. Projected changes in revenues and costs were entered into partial budgets to estimate the change in expected net income when an alternative management approach was substituted for conventional chemical control.

\section{Results}

1991 Field Experiment. Squash Bug Population. Applications of esfenvalerate resulted in significantly $(P \leq 0.05)$ lower squash bug densities $(\approx 1$ bug per plant) on both cultivars than on untreated or parasitoid-released plants (Table 1). Releases of $G$. pennsylvanicum resulted in $\approx 4$ - and 5 -fold reductions in squash bug densities on the susceptible and resistant cultivars, respectively, as compared with the untreated controls. Parasitoid 
Table 2. Mean \pm SE densities of squash bug eggs, eggs parasitized by $G$. pennsylvanicum, and percentages of parasitizntion on susceptible and resistant pumpkins in 1991 and 1992

\begin{tabular}{|c|c|c|c|c|c|c|c|}
\hline \multirow{2}{*}{ Date } & \multirow{2}{*}{$\begin{array}{l}\text { Weeks } \\
\text { after } \\
\text { initial } \\
\text { parasitoid } \\
\text { release }\end{array}$} & \multicolumn{2}{|c|}{ Squash bug egg density } & \multicolumn{2}{|c|}{ No. eggs parasitized } & \multicolumn{2}{|c|}{ Parasitization } \\
\hline & & $\mathrm{JOL} \pm \mathrm{SE}$ & $\mathrm{GSC} \pm \mathrm{SE}$ & $\mathrm{JOL} \pm S E$ & $\mathrm{GSC} \pm \mathrm{SE}$ & JOL & $\csc$ \\
\hline \multicolumn{8}{|c|}{1991} \\
\hline 31 Aug. & 5 & $98 \pm 46.4 A$ & $26 \pm 15.4 \mathrm{~A}$ & $7 \pm 4.9 \mathrm{~A}$ & $1 \pm 1.6 \mathrm{~B}$ & 7 & 4 \\
\hline 13 Sept. & 7 & $24 \pm 20.2 \mathrm{~A}$ & $13 \pm 8.6 \mathrm{~A}$ & $17 \pm 15.6 \mathrm{~A}$ & $7 \pm 8.2 B$ & 70 & 54 \\
\hline 30 Sept. & 9 & $3 \pm 3.0 \mathrm{~A}$ & $2 \pm 3.0 \mathrm{~A}$ & $3 \pm 3.4 \mathrm{~A}$ & $1 \pm 2.7 \mathrm{~A}$ & 100 & 67 \\
\hline \multicolumn{8}{|c|}{1992} \\
\hline 19 Aug. & 5 & $3 \pm 2.4 \mathrm{~A}$ & $14 \pm 1.1 .1 \mathrm{~A}$ & $0 \pm O A$ & $1 \pm 2.9 \mathrm{~A}$ & 0 & 10 \\
\hline 29 Aug. & 6 & $3 \pm 5.5 \mathrm{~A}$ & $5 \pm 7.5 \mathrm{~A}$ & $0 \pm 0 A$ & $3 \pm 5.2 \mathrm{~A}$ & 0 & 60) \\
\hline
\end{tabular}

JOL, Jack-O-Lantern (susceptible); GSC, Green-Striped Cushaw (resistant). Means followed by the same letter are not significantly different between cultivars (GLM, LSD $P \leq 0.05$ ). LSDs were computed using square-root transformed dati.

releases coupled with a resistant pumpkin produced squash bug densities that were 10 times lower than those on untreated susceptible pumpkins. On untreated plants, squash bug densities were about $50 \%$ lower on the resistant GreenStriped Cushaw than on the susceptible Jack-OLantern (Table 1).

Parasitoid Population. No parasitization of squash bug eggs was observed until late August, which was 5 wk after $G$. pennsylvanicum was first released. On both the susceptible and resistant pumpkin cultivars, the percentage of eggs parasitized was inversely related to squash bug egg density which declined throughout the summer (Table 2 ). The rate of parasitization was consistently higher on the susceptible pumpkin Jack-O-Lantern than on the resistant Green-Striped Cushaw. Squash bug egg densities also were uniformly higher on susceptible pumpkins than on resistant pumpkins.

Pumpkin Yields. Yields of U.S. No. 1 pumpkins were significantly greater for both cultivars when squash bugs were managed with insecticides than when parasitoids were released or when no management program was used (Table 3). Pumpkin yields also were significantly greater when parasitoids were used than when no squash bug treat- ment was applied. Production of resistant pumpkins was significantly greater than that of the susceptible pumpkins. The use of biological control and host plant resistance enhanced pumpkin yields (Table 3)

Yields of U.S. No. 2 Jack-O-Lantern pumpkins were highly variable and did not differ statistically among most treatments (Table 3). However, significantly more U.S. No. 2 Green Striped Cushaw pumpkins were produced on biological controltreated and untreated plants than on those treated with insecticide. On untreated plants, the resistant cultivar produced significantly more pumpkins than the susceptible cultivar.

Economic Comparisons. When insecticide was used in place of no squash bug management, expected net income increased more than $\$ 6,000 /$ a (Table 4). When a resistant cultivar was used in place of a susceptible cultivar, net income increased slightly, but was $>100$-fold lower than when insecticide was used. The integration of insecticide with host plant resistance increased expected net income $\$ 1,458 /$ ha over the use of insecticide alone (Table 4).

Prices of commercially produced natural enemies requiring a rearing system similar to that of G. pennsylvanicum ranged from $\$ 0.50$ to $\$ 250$ per

Table 3. Meun \pm SE total weight (kg/ha) of 2 grades of pumpkins from squash bug-susceptible and -resistant cultivars following biological, chemical, or no control in 1991 and 1992

\begin{tabular}{lccccc}
\hline \multirow{2}{*}{ Treatment } & \multicolumn{2}{c}{ U.S. no. 1} & & U.S. no. 2 \\
\cline { 2 - 4 } & JOL \pm SEM & GSC \pm SEM & & JOL \pm SEM & GSC \pm SEM \\
\hline Biological control & $4,767 \pm 3,338 \mathrm{Aa}$ & $12,319 \pm 9,220 \mathrm{Ab}$ & & $1,504 \pm 2,654 \mathrm{Aa}$ & $3,314 \pm 1,672 \mathrm{Aa}$ \\
Chemical control & $20,280 \pm 15,771 \mathrm{Ba}$ & $24,177 \pm 14,813 \mathrm{Ba}$ & & $0 \pm 0 \mathrm{Aa}$ & $512 \pm 74 \mathrm{Ba}$ \\
No treatment & $0 \pm 0 \mathrm{Ca}$ & $2,699 \pm 3,521 \mathrm{Cb}$ & & $0 \pm 0 \mathrm{Aa}$ & $3,383 \pm 2,682 \mathrm{Ab}$ \\
& & 1992 & & \\
Biological control & $2,615 \pm 1,809 \mathrm{Aa}$ & $3,366 \pm 3,985 \mathrm{Aa}$ & & $735 \pm 853 \mathrm{Aa}$ & $4,305 \pm 6,387 \mathrm{Aa}$ \\
Chemical control & $3,741 \pm 2,646 \mathrm{Aa}$ & $5,142 \pm 2,044 \mathrm{Aa}$ & & $499 \pm 650 \mathrm{Aa}$ & $4,904 \pm 3,024 \mathrm{Ab}$ \\
No treattment & $1,026 \pm 2,052 \mathrm{Aa}$ & $3,941 \pm 2,707 \mathrm{Ab}$ & & $205 \pm 354 \mathrm{Aa}$ & $5,285 \pm 2,940 \mathrm{Ab}$ \\
\hline
\end{tabular}

JOL, Jack-O-Lantem (susceptible); GSC, Green-Striped Cushaw (resistant). Means followed by the same letter are not significuntly different (C:LM, LSD, $P \leq 0.05$ ). Uppercase letters are within cultivar; lowercase letters are between cultivars. LSDs were computed using square-root transformed data. 
1,000 individuals. If $G$. pennsylvanicum could be purchased at $\$ 0.50$ per 1,000 parasitoids and pumpkins sold at the current retail price, expected net income would increase by $\$ 1,100$ and $\$ 3,700 /$ ha for biological control and biological control plus host plant resistance, respectively, over that with no squash bug management (Table 4). However, If chemical control were replaced by biological control or biological control combined with host plant resistance, net income would decrease by $\$ 5,400$ and $\$ 2,800 /$ a, respectively.

The cost of grower-reared G. pennsylvanicum, either by individuals or as part of a cooperative program, would be $\$ 70$ per 1,000 parasitoids. If grower-reared parasitoids were used in place of no treatment or chemical control, expected net income would decrease by $\$ 5,000$ and almost $\$ 12,000 / h a$, respectively. This loss would be reduced by 90 and $40 \%$, respectively, if biological control and host plant resistance were used in place of no treatment or chemical contol (Table 4).

1992 Field Experiment. Squash Bug Population. The mean seasonal densities of squash bugs on both the susceptible and resistant pumpkin cultivars were significantly lower when biological or chemical control was applied than when plants were left untreated (Table 1). However, pest densities did not differ significantly between the 2 management tactics. Squash bug densities also did not differ significantly between cultivars on insecticide-free plants. The combined use of natural enemy releases and resistant plants resulted in about a 7 -fold reduction in pest densities compared to untreated susceptible plants (Table 1).

Parasitoid Population. Very few parasitized squash bug eggs were recovered in 1992 and only on the resistant Green-Striped Cushaw. Parasitized eggs were observed during the 5th and 6th wk after G. pennsylvanicum was first released (Table 2).

Pumpkin Yields. Yields of U.S. No. 1 and No. 2 pumpkins did not differ significantly for either cultivar when treated with biological or chemical control (Table 3). There were no significant difference in yields between cultivars for U.S. No. 1 pumpkins when squash bugs were managed using biological or chemical control. Yields of U.S. No. 2 resistant pumpkins were significantly greater than those of U.S. No. 2 susceptible pumpkins when squash bugs were managed with chemical control. Yields (both grades) from the resistant cultivar were significantly greater than yields of the susceptible cultivar when squash bugs were not subjected to either parasitoids or insecticide (Table 3 ).

Economic Comparisons. When insecticide was used in place of no squash bug management on susceptible pumpkins, expected net income increased more than $\$ 200 /$ ha (Table 4). When a resistant cultivar was used instead of a susceptible cultiviar, where no other pest management was applied, the expected increase in net income was $>7$ fold greater than when insecticide was used (Table 4). When insecticide was applied to a resistant cul- tivar, expected net income increased nincfold per hectare over the use of insecticide alone.

When biological control $(\$ 0.50 / 1,000$ parasitoids) was used, expected net income decreased by $\$ 50 /$ ha compared with no pest management and almost $\$ 900 /$ ha compared with chemical control (Table 4). When biological control was combined with host plant resistance, net income increased by $\$ 250$ and $\$ 1,100 /$ ha over that of chemical control or no pest management, respectively. If grower reared parasitoids $(\$ 70 / 1,000)$ were used instead of purchased parasitoids, expected net incomes would decrease substantially (Table 4).

\section{Discussion}

Population Effect. In both 1991 and 1992, the use of insecticides resulted in the most consistent and most effective suppression of squash bug populations. The release of egg parasitoids also had a measurable effect on squash bug populations. However, this effect was delayed until late in the season. Consequently, pest densities in the biological control plots were consistently higher throughout the season than those in plots that were treated with insecticides. The use of a resistant cultivar had a substantial suppressive effect on squash bug populations in 1991. However, host plant resistance was not as effective as chemical control in reducing squash bug densities in either year.

Our experiments suggest that combining 2 alternative management tactics-biological control and host plant resistance-for the squash bug may result in a greater effect on the pest population than the use of either tactic alone. For example, in 1991. the difference in mean seasonal squash bug densities on plants treated with parasitoids and those on insecticide-treated plants was reduced more than double when parasitoids were released on resistant plants. Biological control alone resulted in lower seasonal squash bug densities in 1991 than when host plant resistance was used as the only form of pest management. However, as demonstrated by Vogt and Nechols (1993), plant resistance is most effective against early instar nymphs. Therefore, if cultivars that have similar resistance. as Green-Stripped Cushaw are used, the squash bug likely will be controlled early in the season before unacceptably high pest populations levels develop. It remains to be shown whether augmentative release strategies can be developed to control squash bug egg populations early in the season. The parasitoid to host release ratio we used was based on an estimate of the reproductive potential of G. pennsylvanicum in the laboratory. If adult parasitoid mortality or other factors prevented this reproductive potential from being realized, this could explain the low level of squash bug population suppression early in the season. This explanation is supported by our finding that parasitoid emergence was not observed until $\approx 32 \mathrm{~d}$ after the lst release was made. 
Table 4. Projected changes in revenue, cost, and expected net income for various squash bug management tactic: when compared with conventional chemical control or no management

\begin{tabular}{|c|c|c|c|}
\hline \multirow{2}{*}{ Management tactics } & \multicolumn{3}{|c|}{ Change in } \\
\hline & Revenue (\$) & Cost $(\$)$ & Net income (\$) \\
\hline \multicolumn{4}{|c|}{1991} \\
\hline Chemical control/no treatment & 6,692 & 184 & 6,508 \\
\hline HPR/no treatment & 1,771 & 1,721 & 58 \\
\hline Chemical control + HPR/no treatment & 8,111 & 145 & 7,966 \\
\hline \multicolumn{4}{|l|}{ Commercially purchased parasitoids } \\
\hline Biological control/no treatment & 1,964 & 804 & 1,160 \\
\hline Biological control/chemical control & 521 & 5,923 & $(5,402)$ \\
\hline Biological control + HPR/no treatment & 4.927 & 1,164 & 3,763 \\
\hline Biological control + HPR/chemical control & 992 & 3,791 & $(2,799)$ \\
\hline \multicolumn{4}{|l|}{ Grower-reared parasitoids } \\
\hline Biological controlno treatment & 1,965 & 7,148 & $(5,183)$ \\
\hline Biological control/chemical control & 521 & 12,267 & $(11,746)$ \\
\hline Biological control + HPR/no treatment & 4,927 & 5,456 & (529) \\
\hline Biological control + HPRchemical control & 992 & 8,083 & $(7,091)$ \\
\hline \multicolumn{4}{|c|}{1992} \\
\hline Chemical control/no treatment & 972 & 748 & 224 \\
\hline HPR/no treatment & 2,283 & 678 & 1,605 \\
\hline Chemical control $+\mathrm{HPR} /$ no treatment & 2,580 & 534 & 2,046 \\
\hline \multicolumn{4}{|l|}{ Commercially purchased parasitoids } \\
\hline Biological control/no treatment & 662 & 717 & $(55)$ \\
\hline Biological control/chemical control & 191 & 1,089 & (898) \\
\hline Biological control + HPR/no treatment & 1,838 & 740 & 1,098 \\
\hline Biological control + HPR/chemical control & 1,120 & 864 & 256 \\
\hline \multicolumn{4}{|l|}{ Grower-reared parasitoids } \\
\hline Biological control/no treatment & 662 & 5,084 & $(4,422)$ \\
\hline Biological control/chemical control & 191 & 5,456 & $(5,265)$ \\
\hline Biological control + HPR/no treatment & 1,838 & 2,959 & $(1,121)$ \\
\hline Biological control + HPR/chemical control & 1,112 & 3,083 & $(1,963)$ \\
\hline
\end{tabular}

HPR, host plant resistance. Numbers enclosed in parentheses are negative values.

Relative differences in fruit yields and quality among treatments paralleled differences we observed in squash bug population densities during 1991. When squash bugs were managed with scheduled insecticide applications, both the susceptible and resistant cultivars yielded very high percentages of U.S. No. 1 pumpkins. Yields of U.S. No. 1 Jack-O-Lantern pumpkins were much lower, and yields of U.S. No. 2 grade were much higher, when biological control was used as an alternative to chemical control. Integrating biological control with host plant resistance improved the quality of pumpkin yields. In addition, the yield of U.S. No. 1 pumpkins from parasitoid-treated resistant plants increased substantially over that when host plant resistance was used as a single tactic.

In 1992, abnormally wet, cool conditions appeared to have an adverse effect on local squash bug populations. Weather also may have influenced the effectiveness of squash bug management tactics. For example, the increased precipitation during 1992 apparently reduced insecticide efficacy because squash bug densities were uniformly higher on insecticide-treated plants in 1992 then in 1991. However, the conditions in 1992 apparently did not reduce the effect of $G$. pennsylvanicum because mean seasonal squash bug densities on both cultivars treated with biological control were substantially lower in 1992 than in 1991. The weather conditions in 1992 also appeared to have had less of an effect on squash bug densities on resistant plants than on susceptible plants.

Wet, cool weather during 1992 may have had a direct negative effect on the quality and yield of pumpkins. For example, although squash bug populations were uniformly lower in 1992 than in 1991 in all treatments, both pumpkin cultivars produced substantially fewer U.S. No. 1 pumpkins and more of the lower-quality U.S. No. 2 pumpkins in 1992. The reduction in pumpkin quality and yield in 1992 was not as great for the resistant GreenStriped Cushaw, than the susceptible Jack-O-Lantern.

Economic Comparisons. In 1991, the revenues from pumpkin yields were substantially greater than the costs of using insecticide in place of no pest management. In contrast, costs associated with biological suppression tactics were very high relative to revenues obtained from pumpkin yields. As a result, the net return per hectare was only $\$ 0.09-\$ 0.26$ per dollar invested when biological suppression tactics were compared with chemical control. However, for growers who prefer to use noninsecticidal forms of pest management, the net return per hectare compared with no treatment 
would be $\$ 2.44$ per dollar invested for biological control and $\$ 4.23$ per dollar invested for biological control plus host plant resistance.

One means of offsetting higher costs is to charge consumers more. According to a survey we conducted (Olson et al. 1995), consumers were willing to pay a premium price of $\$ 0.52 / \mathrm{kg}$ and $\$ 0.41 / \mathrm{kg}$ for U.S. No. 1 and No. 2 pumpkins, respectively, not treated with insecticides. Based on current cost data, if growers were to integrate biological control with host plant resistance, nonchemical pest management could be as economical as chemical control. This assumes that parasitoids could be produced commercially at a maximum of $\$ 0.50 / 1,000$, and that chemical control costs and benefits remain at the levels we estimated.

For the combination of greenhouse-reared parasitoids with host plant resistance to be economically feasible, growers would have to raise pumpkin prices to levels that only $2 \%$ of the consumers we polled would be willing to pay (Olson et al. 1995). Thus, a biological control-based squash bug management program using grower-produced $G$. pennsylvanicum does not appear feasible at present.

In 1992, noticeable differences in costs and revenues were associated with each treatment compared with 1991. These differences appear to be related to the negative effects that the wet, cool weather in 1992 had on squash bug populations, and the differential effects of weather on pest management tactics, fruit yields and fruit quality. Where insecticide was used in 1992, the net return per dollar invested per hectare was substantially lower than that estimated in 1991. Therefore, it may not pay to treat with insecticides in years when weather conditions are similar to those in 1992. Where biological control was used, costs were much lower relative to revenues in 1992 than in 1991. As a result, the net dollar return per dollar invested per hectare was somewhat higher in 1992 than in 1991. Therefore it may be economically feasible to use biological control during production seasons when cool wet weather persist.

To improve the feasibility of biological control as a pest management approach for squash bugs, we recommend that a number of ecological and economic factors be considered further. For example, because $G$. pennsylvanicum is found naturally at low levels late in the production season, a knowledge of the overwintering biology of this egg parasitoid may help in the conservation of natural populations, thereby reducing the need for releasing as many commercially reared parasitoids early in the season. In addition, our recent studies suggest that sources of adult parasitoid nutrition may be readily available throughout the crop season in the form of extrafloral nectaries (Olson and Nechols 1995). A more complete study of the adult nutritional needs of $G$. pennsylvanicum, and how these needs may differ very early or very late in the season, may help in the conservation of augmented parasitoids.
The techniques by which parasitoids are released also are very important determinants of parasitization rates in the field (Ridgway et al. 1977). In our experiments, adult $G$. pennsylvanicum was released uniformly with respect to host egg density. It is unlikely that growers would accept this procedure because it is time and labor intensive. Therefore, research is needed to determine whether and how a more centralized release strategy affects the impact of this parasitoid on squash bug populations. In addition, further studies are needed to determine the optimal time to release parasitoids to obtain an impact on squash bug populations earlier in the season.

Combining host plant resistance with biological control did not reduce squash bug densities to levels observed when insecticide was used. Therefore, squash or pumpkin cultivars that have a higher level of resistance than the one tested in our studies need to be identified or developed.

For commercial pumpkin production, the profits associated with any biological suppression approach need to be competitive with those obtained for chemical control. Therefore, further studies are needed to determine whether higher relcase ratios will produce higher parasitization rates, and whether resulting fruit production and revenues offset or exceed costs to growers. In addition, because the current system of rearing $G$. pennsylvanicum requires substantial space and labor costs, techniques for long-term storage of parasitized or unparasitized squash bug eggs would decrease the time during which space and labor costs would be required.

When using chemical control, the purchase of insecticides and associated labor for its application, are the main costs recognized. Environmental costs resulting from insecticides currently are not considered in most pest management programs. If environmental costs were to be built into the current costs of chemical control (Higley and Wintersteen 1992), this might decrease the difference in profit between conventional chemical control and biological suppression for squash bug management, thus increasing the economic feasibility of alternative approaches.

Although cucumber beetles (spotted and striped) were found on flowers on both the susceptible and resistant plants not treated with insecticide, they did not appear to damage the plants. However, during production seasons when cucumber beetles are at or above damaging levels (Wilson et al. 1977), chemical managemient that is least harmful to $G$. pennsylvanicum should be used. Cucurbitacins-secondary chemicals that are found in most cucurbits-are arrestants and feeding stimulants for cucumber beetles (Wilson et al. 1977; Metcalf et al. 1987; Lance and Sutter 1990, 1992). These cucurbitacins have been incorporated with insecticides to produce a bait, that contains very small amounts of insecticide (Metcalf et al. 1987; Lance 1988; Lance and Sutter 1990, 1992). 
Studies are needed to determine how augmented G. pennsylvanicum might be affected by a cucurbitacin-insecticide bait applied to a pumpkin field. In addition, it will be necessary to determine if the premium price that consumers are willing to pay for biological control treated pumpkins will be sufficient to pay for the additional cost of managing cucumber beetles.

Currently, our data suggest that biological control of squash bugs does not appear to be a feasible management approach for commercial pumpkin growers. However, an integrated approach that combines biological control with host plant resistance appears to have potential as an alternative to chemical control. The degree of success in implementing biological control and host plant resistance will depend both on cost-effectiveness and the ability to maintain densities of squash bugs and yields comparable to those attained when using insecticides.

\section{Acknowledgments}

We thank R. A. Higgins, C. W. Marr, J. C. Reese, and A. B. Stevens (Kansas State University) for reviewing an earlier version of the manuscript. We thank A. B. Stevens for labor and space cost data for plant production in greenhouses. We appreciate the technical assistance of $W$. Lamont, C. Leaming, D. Rich, and E. Vogt (Kansas State University). This is contribution number 95-433-J from the Kansas Agricultural Experiment Station.

\section{References Ciled}

Beurd, R. L. 1940. The biology of Anasa tristis De Geer, with particular reference to the tachinid parasite, Trichopoda pennipes Fabr. Conn. Agric. Exp. Stn. Bull. 440: 597-679.

Boehlje, M. D., and V. R. Eidman. 1984. Farm management. Wiley, New York.

Bonjour, E. L., and W. S. Fargo. 1989. Host effects on the survival and development of Anasa tristis (Heteroptera: Coreidae). Environ. Entomol. 18: 10831085.

Dietrick, E. J., and R. van den Bosch. 1957. Insectary propagation of the squash bug and its parasite Trichopoda pennipes Fabr. J. Econ. Entomol. 50: 627-629.

Fargo, W. S., P. E. Rensner, E. L. Bonjour, and T. L. Wagner. 1988. Population dynamics in the squash bug (Heteroptera: Coreidae)-squash plant (Cucurbitae: Cucurbitaceae) system in Oklahoma. I. Econ. Entomol. 81: 1073-1.079.

Fielding, D. J. 1987. Oviposition in the squash bug. Ill. Veg. Res. Rep. Hortic. Sci. 62: 5-8.

1988. Photoperiodic induction of diapause in the squash bug Anasa tristis. Entomol. Exp. Appl. 48: 187-193.

Fielding, D. J., and W. G. Ruesink. 1988. Prediction of egg and nymphal developmental times of the squash bug (Hemiptera: Coreidae) in the field. I. Econ. Entomol. 81: 1377-1382.

Headley, J. C., and M. A. Hoy. 1987. Benefit/cost analysis of an integrated mite management program for almonds. J. Econ. Entomol. 80: 555-559.
Higley, L. G., and W. K. Wintersteen. 1992. A novel approach to environmental risk assessment of pesticides as a basis for incorporating environmental costs into economic injury levels. Am. Entomol. 38: 34-39.

Lance, D. R. 1988. Potential of 8-methyl-2-decyl propranoate and plant-derived volatiles for attracting corn rootworm beetles (Coleoptera: Chrysomelidae) to toxic bait. J. Econ. Entomol. 81: 1359-1362.

Lance, D. R., and G. R. Sutter. 1990. Field-cage and laboratory evaluations of semiochemical-based baits for managing western corn rootworm (Coleoptera: Chrysomelidae). J. Econ. Entomol. 83: 1085-1090.

1992. Field tests of a semiochemical-based toxic bait for suppression of corn rootworm beetles (Coleoptera: Chrysomelidae). J. Econ. Entomol. 85: 967-973.

Metcalf, R. L., J. E. Ferguson, R. Lampman, and J. F. Andersen. 1987. Dry cucurbitacin-containing baits for controlling diabroticite beetles (Coleoptera: Chrysomelidae). J. Econ. Entomol. 80: 870-875.

Nechols, J. R. 1985. The squash bug: biology and management. Kans. Coop. Ext. Serv. Publ. MF-758.

1987. Voltinism, seasonal reproduction, and diapause in the squash bug (Heteroptera: Coreidae) in Kansas. Environ. Entomol. 16: 269-273.

1988. Photoperiodic responses of the squash bug (Heteroptera: Coreidae): diapause induction and maintenance. Environ. Entomol. 17: 427-431.

Nechols, J. R., J. L. Tracy, and E. A. Vogt. 1989. Comparative ecological studies of indigenous egg parasitoids (Hymenoptera: Scelionidae: Encyrtidae) of the squash bug Anasa tristis (Hemiptera: Coreidae). J. Kans. Entomol. Soc. 62: 177-188.

Norgaurd, R. B. 1988. The biological control of cassava mealybug in Africa. Am. J. Agric. Econ. 70: 366371.

Novero, E. S., R. H. Painter, and C. V. Hall. 1962. Interrelations of the squash bug, Anasa tristis, and six varieties of squash (Cucurbita spp.). J. Econ. Entomol. 55: 912-919.

Olson, D. L., and J. R. Nechols. 1995. Effects of squash leaf trichome exudates and honey on adult feeding, survival, and fecundity of the squash bug (Heteroptera: Coreidae) egg parasitoid Gryon pennsylvanicum (Hymenoptera: Scelionidae). Environ. Entomol. 24: 454-458.

Olson, D. L., J. R. Nechols, and C. W. Marr. 1995. Consumers' preference for insecticide-free pumpkins in eastern Kansas. Hort'Technology 5: 274-276.

Paige, J., III, W. P. Morrison, J. K. Wangberg, and R. J. Whitworth. 1989. Ovipositional host association of Anasa tristis (De Geer) and various Cucurbita cultivars on the Texas high plains. I. Agric. Entomol. 6: 5-8.

Palumbo, J. C., W. S. Fargo, and E. L. Bonjour. 1990. Within plant distribution of squash bug (Heteroptera: Coreidae) adults and egg masses in vegetative stage summer squash. Environ. Entomol. 20: 391-95.

Palumbo, J. C., W. S. Fargo, and E. L. Bonjour. 1991. Colonization and seasonal abundance of squash bugs (Heteroptera: Coreidae) on summer squash with varied planting dates in Oklahoma. I. Econ. Entomol. 84: 224-229.

Ridgway, R. L., E. G. King, and J. L. Carrillo. 1977. Augmentation of natural enemies for control of plant pests in the western hemisphere, pp. 379-416. In R. L. Ridgway and S. B. Vinson [eds.], Biological control 
by augmentation of natural enemies. Plenum, New York.

SAS Institute. 1990. SAS/STAT user's guide, version 6, 4th ed., vol. 2. SAS Institute, Cary, NC.

Schell, S. C. 1943. The biology of Hadronotus ajax Girault (Hymenoptera: Scelionidae) a parasite in the eggs of the squash bug (Anasa tristis DeGeer). Ann. Entomol. Soc. Am. 36: 625-635.

USDA. 1983. United States standards for grades of fall and winter type squash and pumpkin. USDA, Agricultural Marketing Service, Washington, DC.

Vout, E. A., and J. R. Nechols. 1993. Responses of the squash bug (Hemiptera: Coreidae) and its egg parasitoid, Gryon pennsylvanicum (Hymenoptera:
Scelionidae) to three Cucurbita cultivars. Environ. Entomol. 22: 238-245

Wilson, M. C., A. C. York, and A. V. Provonsha. 1977. Practical insect pest management: insects of vegetables and fruit. Waveland, Prospect Ileights, II.

Worthley, H. N. 1924. The squash bug in Massachusetts. J. Econ. Entomol, 16: 73-79.

Zavala, M. S. 1991. Relative toxicity of selected pesticides to the squash bug, Anasa tristis De Geer (Hemiptera: Coreidae) and its egg parasitoid, Cryon pennsylvanicum (Hymenoptera: Scelionidae). M.S. thesis, Kansas State University, Manhattan, KS.

Received for publication 17 May 1995; accepted 29 January 1996. 